\title{
VITRIFICATION OF SURROGATE MIXED WASTES IN A GRAPHITE ELECTRODE ARC MELTER
}

Nick R. Soelberg, Andrea G. Chambers, Lynn Ball, and Gary Anderson Idaho National Engineering Laboratory

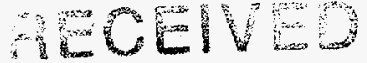

OCT 271995

OSTI

William K. O'Connor

U.S. Bureau of Mines, Albany Research Center

\section{ABSTRACT}

Demonstration tests for vitrifying mixed wastes and contaminated soils have been conducted using a small $(800 \mathrm{kVA})$, industrial-scale, three-phase $\mathrm{AC}$, graphite electrode furnace located at the Albany Research Center of the United States Bureau of Mines (USBM). The feed mixtures were nonradioactive surrogates of various types of mixed (radioactive and hazardous), transuranic-contaminated wastes stored and buried at the Idaho National Engineering Laboratory (INEL). The feed mixtures were processed with added soil from the INEL.

Objectives being evaluated include (a) equipment capability to achieve desired process conditions and vitrification products for different feed compositions, (b) slag and metals tapping capability, (c) partitioning of transuranic elements and toxic metals among the furnace products, (d) slag, fume, and metal products characteristics, and (e) performance of the feed, furnace and air pollution control systems.

The tests were successfully completed in mid-April 1995. A very comprehensive process monitoring, sampling and analysis program was included in the test program. Sample analysis, data. reduction, and results evaluation are currently underway. Initial results indicate that the furnace readily processed around $20,000 \mathrm{lb}$ of widely ranging feed mixtures at feedrates of up to $1,100 \mathrm{lb} / \mathrm{hr}$. Continuous feeding and slag tapping was achieved. Molten metal was also tapped twice during the test program. Offgas emissions were efficiently controlled as expected by a modified air pollution control system.

\section{INTRODUCTION}

Some wastes and soils at the Idaho National Engineering Laboratory (INEL) and other DOE sites are contaminated with long-lived transuranic (TRU) radionuclides and hazardous organic compounds and metals. The INEL has both buried and retrievably stored wastes at the Transuranic Storage Area of the Radioactive Waste Management Complex (RWMC). These wastes consist of various solid, heterogeneous combustibles, structural metals, organic and inorganic sludges, laboratory wastes, and construction debris. A large amount of the interstitial soil is now also expected to have some contamination. Many of the buried waste sites have been placed on the US Environmental Protection Agency (EPA) National Priority List, which require appropriate remediation in accordance with the CERCLA (Comprehensive Environmental Response, Compensation and Liability Act) process. Stored wastes also require appropriate treatment for final disposal to meet (a) EPA land disposal restrictions for hazardous components, and (b) DOE radiological disposal system requirements for radionuclides.

Various treatment technologies are being evaluated and demonstrated for potential application to these types of wastes. The most desirable approach for long-term stabilization of the long-lived TRUs is believed to be melting and dissolution of the TRU elements, as oxides, into a slag at high 


\section{DISCLAIMER}

Portions of this document may be illegible in electronic image products. Images are produced from the best available original document. 
temperatures. Upon cooling, the slag can solidify into a durable glass or crystalline rock-like matrix. This type of matrix can also immobilize toxic metals in order to eliminate hazardous toxicity characteristics. A recent technical review at the $\mathrm{INEL}^{1}$ of various melter technologies has resulted in a recommendation that a graphite electrode melter system is most applicable to the types of TRUcontaminated, mixed waste streams stored and buried at the INEL. With appropriate design and operation, this type of melting system can suitably treat both the radioactive and the hazardous components of mixed wastes by immobilizing the radionuclides and toxic metals and destroying the hazardous organic compounds. The final waste volume is also substantially reduced, with (a) essentially no added glass formers or other additives, (b) reduction of much of the solid mass via volatilization and oxidation reactions, and (c) densification of the remaining solid material by fusing the feed material and eliminating void space. The resulting slag product is also far more homogenous and simpler to characterize and control than the input heterogenous waste.

Waste processing application demonstration tests have been conducted using a small, industrial-scale, three-phase AC, graphite electrode furnace system. This system is located at the Albany Research Center of the United States Bureau of Mines (USBM). Baseline tests were conducted in 1993 using non-radioactive surrogate feed mixtures representing a range of retrieved mixed wastes that have been incinerated. ${ }^{2}$ The tests completed in April 1995 used surrogate feed materials that represented as-received mixed wastes without prior incineration.

This paper briefly describes the facility, feed mixtures, test program, and very early initial results. The sample analyses and data reduction are not yet complete. Further results and conclusions are planned following sample and data evaluation.

Scope and Objectives

The current series of processing tests has focused on demonstrating the tolerance of the graphite electrode melter system for stably processing heterogeneous solid wastes containing high levels of organics. ${ }^{3}$ Successful demonstration of melter processing tolerance to widely varying feed materials that contain amounts of organics, chlorides, nitrates, and other volatile materials at levels representative of the INEL will enable the elimination of an upfront incineration step in the conceptual treatment process.

Tests were conducted during continuous system operation over a 66 -hr time period. A very comprehensive process monitoring, sampling and analysis program was included. Over 60 process variables were continuously or manually monitored and recorded for on-line process control. These included feedrate, voltage, current, power, fuel, cooling water, air, and offgas flowrates, and temperatures at many locations in the system. Samples of the resultant slag and metal products and the offgas solids were collected for composition, crystalline phase, oxidation state, leachability, and other analyses. Offgas analyses were performed continuously at several locations in the system including the furnace plenum and outlet and several locations in the offgas system.

Objectives for these tests included evaluation of (a) equipment capability to achieve desired vitrification process conditions and products over a range of mixed waste/soil compositions, (b) continuous slag tapping and on-demand metals tapping capability, (c) partitioning (distribution) of TRUs (surrogates) and toxic metals among the slag, fume, and tapped metals phases, (d) composition, homogeneity, and properties of the slag, fume, and metal products, (d) furnace gas temperatures and retention of toxic metals in the slag with a layer of unmelted feed (cold top) on top of melted slag, and (e) performance of the feed, furnace and air pollution control systems. 


\section{EQUIPMENT DESCRIPTION}

The melter system (Figure 1) consists of a continuous feed system, furnace, air pollution control system (APCS), and facility power, water, instrumentation, and controls. The system can process materials at a maximum rate of $2,000 \mathrm{lb} / \mathrm{hr}$, depending on the characteristics of the materials.

The feed system (not shown in the figure) is designed for measuring, controlling, and delivering aggregate and soil-type materials of sizes less than about $1 / 2$ in. diameter to the furnace. The feed system includes a receiving bin, bucket elevator, metering bin with calibrated delivery screws, rotating air lock, splitter screw, and two feed screws. Materials to be melted are delivered uniformly to the furnace through four water-cooled feed tubes which extend through ports in the furnace roof to within 18 inches of the surface of the molten slag. The feed system is sealed from the receiving bin onward to control fugitive dust release. A rotary air lock seal downstream of the metering bin minimized air inleakage into the furnace from the feed system. Primary combustion air was injected into the furnace through the feed tubes.

The furnace is a stationary, refractory-lined, small industrial-scale electric arc melting furnace that is sealed for atmosphere control. The furnace has three moveable 4 in. diameter solid graphite electrodes, automatic power, and electrode vertical positioning control. Power is supplied by a fully instrumented $800 \mathrm{kVA}$ 3-phase supply. The electrodes are positioned at the apexes of an equilateral triangle 11.25 in. from electrode center to center and extend through ports in the furnace roof. The feed tubes, furnace roof and sidewalls, and copper slag tapping fixture are water cooled. Slag can be continuously tapped from the furnace; metal is tapped (and the hearth is emptied) through a taphole in the bottom center of the hearth.

The furnace shell bottom is lined with five inches of chromic oxide-alumina bonded, $90 \%$ alumina (Ruby) firebricks. Five courses of ruby key bricks shape the hearth and form the sidewall up to the steel shelf that is 28 in. above the bottom and approximately 7 in. above the slag tap hole. One inch of dry phosphate bonds the silicon carbide $(\mathrm{SiC})$ ramming mix that was placed between the steel bottom and first course of ruby straights and also between the ruby keys and the sidewall to improve heat transfer. The upper sidewall is lined with 4.5 inches of insulating fire brick ( $70 \%$ alumina). Fiberfrax batting 1 inch thick is placed between the sidewall and arch brick as added insulation. The hearth is rammed to 6 inches deep at the center with Ruby ramming mix. The roof is lined with 4 inches of plastic refractory ( $85 \%$ alumina). The finished inside diameter of the furnace is about 46 in. at mid-height. The capacity of the hearth is approximately $5 \mathrm{ft}^{3}$.

The furnace roof, slag tap hole, slag launder, metal tap hole collar, power supply transformer, and electrode arms, cables, and clamps are all internally water cooled. The furnace shell is externally cooled by a curtain of water cascading down the exterior wall from the annular distribution trough near the shell top.

A new "dry-wet" air pollution control system (APCS) was designed to completely oxidize the furnace offgases and control particulate, toxic metals and acid gas emissions. The APCS includes a thermal oxidizer close-coupled to the melter. The thermal oxidizer is designed for a maximum temperature of $2,400 \mathrm{~F}$. A water spray cooler rapidly quenches the offgas to around $500 \mathrm{~F}$, followed by an air-dilution temperature quench section to further cool the gas to $300 \mathrm{~F}$. A cyclone removes coarse particulate upstream of the pulse-jet baghouse. The baghouse has a design maximum gas flowrate of $10,000 \mathrm{acfm}$. A wet scrubber follows the baghouse for acid gas removal, with a design gas outlet temperature of around $153 \mathrm{~F}$. A cooler/condenser provides further offgas cooling and removes condensed water droplets, with a design outlet temperature of $90 \mathrm{~F}$. This is followed by 
a hot water-heated reheater to raise the offgas temperature above the dewpoint, with a design gas outlet temperature of $105 \mathrm{~F}$. The reheater is necessary to prevent moisture condensation in the downstream equipment and to minimize the steam plume at the stack outlet. An activated carbon filter for controlling $\mathrm{Hg}$ and other gaseous toxic metals and contaminants is followed by a High Efficiency Particulate-Air (HEPA) filter, rated to remove $99.98 \%$ of particulate greater than 0.3 microns.

\section{FEED MIXTURES}

The feed mixtures for these tests were designed to be non-radioactive surrogates for mixed, transuranic-contaminated wastes stored at the INEL Transuranic Storage Area. There are over 100 different waste streams at this location, representing a wide variety of different waste materials. ${ }^{4}$ These have been grouped according to physical similarity into 19 different categories such as combustibles (the largest category at around $26 \%$ of the total volume), metals ( $21 \%$ of the total volume), and sludges (11\% of the total volume). Surrogate waste mixtures were chosen to represent three different types of wastes for this demonstration, (a) a nominal mixture ${ }^{5}$ of buried waste and soil (denoted Nom-xx), (b) liquid chlorinated and non-chlorinated organics that were absorbed in silicabased absorbents (denoted S-Xx), and (c) solid combustibles such as paper, rags and plastics (denoted $\mathrm{C}-\mathrm{xx}$ ). The $\mathrm{xx}$ indicates the ratio of soil to waste in the waste/soil mixture, expressed as percent. The compositions of the surrogate wastes are shown in Tables 1 and 2. Soil was added to these mixtures in proportions commensurate to the expected amounts of contaminated soil, and to produce an expectedly acceptable waste form based on earlier modelling. Some lime $(\mathrm{CaO})$ was added to each mixture of waste and soil to increase the basicity of product slag to 0.7 . Cerium oxide, a TRU surrogate, was also added to each mixture to provide approximately 0.5 percent $\mathrm{CeO}_{2}$ in the product slags. The nominal mixture includes large proportions (by weight) of metals (around 38\%), solid combustibles $(24 \%)$, and silicated organics $(23 \%)$, with smaller proportions of nitrates $(7.3 \%)$ and hydroxides $(7.7 \%)$.

\section{TEST PROGRAM}

During the demonstration tests, instrumentation was monitored and samples were collected to characterize the performance of the melter and offgas systems. Operating parameters that were varied during the test program were the feed mixture, the feedrate, the amount of cold top, primary air addition (air injected with the feed through the feed tubes), and power levels. These parameters are related to the ability of the furnace to process real wastes that contain various metals that may be relatively volatile, and organics that include both volatile organic and fixed carbon components.

Operating parameters that were not purposely varied (but that did vary during the tests) and which were monitored included (a) oxidation conditions in the slag and in the furnace plenum (excess $\mathrm{O}_{2}$ in the plenum just above the melt; slag and metal $\mathrm{C}$ content and $\mathrm{Fe}^{+2} / \mathrm{Fe}^{+3}$ ratio), (b) furnace offgas flowrate, temperature, composition, (c) slag temperature, viscosity, basicity, (d) entrained and volatilized particulate, (e) afterburner temperature, and (f) baghouse differential pressure, temperature, and cloth/gas ratio.

Measurements and Sample Collection

Process monitoring and data acquisition was performed using a computer data acquisition system (DAS) and by using manually recorded logs and data sheets. The DAS was automatically updated every minute. There were over 60 monitored parameters including the (a) feedrate, (b) 
Table 1. Composition for the nominal feed mixture (without added soil, lime, or cerium oxide).

\begin{tabular}{|c|c|c|c|c|c|c|c|}
\hline \multirow[b]{2}{*}{ Component } & \multicolumn{6}{|c|}{ Composition in Weight \% } & \multirow[b]{2}{*}{\begin{tabular}{|l} 
Total of \\
Each \\
Group \\
in Nom. \\
Comp.
\end{tabular}} \\
\hline & $\begin{array}{c}\text { Hazard- } \\
\text { ous } \\
\text { Metals }\end{array}$ & $\begin{array}{c}\text { Solid } \\
\text { Com- } \\
\text { busti- } \\
\text { bles }\end{array}$ & $\begin{array}{l}\text { Sili- } \\
\text { cated } \\
\text { Org. } \\
(743)\end{array}$ & \begin{tabular}{|c|} 
Nitrate \\
(Evap.) \\
Salts \\
$(745)$ \\
\end{tabular} & \begin{tabular}{|c|} 
Metal \\
Hydroxide \\
Sludges \\
$(741,742)$
\end{tabular} & $\begin{array}{c}\text { Nominal } \\
\text { Comp. }\end{array}$ & \\
\hline Carbon steel & 60.00 & & & & & 22.50 & \\
\hline Stainless steel & 30.50 & & & & & 11.44 & \\
\hline Aluminum & 5.00 & & & & & 1.88 & \\
\hline Zirconium & 2.50 & & & & & 0.94 & \\
\hline Copper & 1.50 & & & & & 0.56 & \\
\hline Lead & 0.50 & & & & & 0.19 & 37.50 \\
\hline LD Polyethylene, (-CH2-CH2-) & & 25.90 & & & & 6.29 & \\
\hline Wood pellets (paper, wood, cloth) & & 63.80 & & & & 15.50 & \\
\hline Neoprene rubber, (-CH2CCl-CHCH2-)n & & 10.30 & & & & 2.50 & \\
\hline \begin{tabular}{|l|} 
Oil Dri sorbent \\
\end{tabular} & & & & & & & 24.30 \\
\hline Texaco Regal Oil, $(\mathrm{CH} 2) \mathrm{n}$ & & & 22.59 & & & 3.69 & \\
\hline Wheel bearing grease, $(\mathrm{CH} 2) n$ & & & 2.73 & & & 0.44 & \\
\hline $\mathrm{PVC},(-\mathrm{C} 2 \mathrm{H} 3 \mathrm{Cl}-)$ & & & 16.95 & & & 9.70 & \\
\hline Microcel E & & & 35.20 & & & 5.74 & \\
\hline Oil·Dri & & & 22.54 & & & 3.68 & \\
\hline HD Polyethylene, (-CH2-CH2-) & & & & & & & 23.25 \\
\hline $\mathrm{NaNO} 3$ & & & & 36.97 & & 2.70 & \\
\hline KNO3 & & & & 18.48 & & 1.35 & \\
\hline $\mathrm{NaCl}$ & & & & 2.11 & & 0.15 & \\
\hline $\mathrm{Na} 2 \mathrm{SO} 4$ & & & & 2.03 & & 0.15 & \\
\hline $\mathrm{NaOH}$ & & & & 2.03 & & 0.15 & \\
\hline Water & & & & 38.37 & & 2.80 & \\
\hline LD Polyethylene, (-CH2-CH2-) & & & & & & & 7.29 \\
\hline $\mathrm{Al}(\mathrm{OH}) 3$ & & & & & 15.00 & 1.15 & \\
\hline $\mathrm{Fe}(\mathrm{OH}) 3$ & & & & & 14.07 & 1.08 & \\
\hline $\mathrm{Ca}(\mathrm{OH}) 2$ & & & & & 8.60 & 0.66 & \\
\hline $\mathrm{Mg}(\mathrm{OH}) 2$ & & & & & 10.31 & 0.79 & \\
\hline $\mathrm{KOH}$ & & & & & 9.64 & 0.74 & \\
\hline $\mathrm{H} 2 \mathrm{O}$ & & & & & 27.25 & 2.09 & \\
\hline Portland Cement & & & & & 15.12 & 1.16 & \\
\hline LD Polyethylene, (-CH2-CH2-) & & & & & & & 7.66 \\
\hline Totals & 100.00 & 100.00 & 100.00 & 100.00 & 100.00 & 100.00 & 100.00 \\
\hline
\end{tabular}

Table 2. Compositions of the $\mathrm{C}$ and $\mathrm{S}$ feed mixtures.

\begin{tabular}{|c|c|c|}
\hline \multirow[b]{2}{*}{ Component } & \multicolumn{2}{|c|}{ Comp. in Weight \% } \\
\hline & $\begin{array}{l}\text { Silicated } \\
\text { organics }\end{array}$ & $\begin{array}{l}\text { Com- } \\
\text { busti- } \\
\text { bles }\end{array}$ \\
\hline Carbon steel & & 1.77 \\
\hline Stainless steel & & 0.21 \\
\hline Aluminum & & 1.11 \\
\hline Cadmium & & 0.04 \\
\hline Copper & & 0.37 \\
\hline Lead & & 0.04 \\
\hline LD Polyethylene & 3.39 & 31.73 \\
\hline Wood pellets (wood) & & 42.57 \\
\hline Neoprene rubber & & 1.34 \\
\hline Oil Dri sorbent & & 1.66 \\
\hline Texaco Regal Oil, $(\mathrm{CH} 2) n$ & 16.40 & \\
\hline Wheel bearing grease, $(\mathrm{CH} 2) \mathrm{n}$ & 1.98 & \\
\hline $\mathrm{PVC},(-\mathrm{CH} 3 \mathrm{Cl}-)$ & 42.97 & 7.89 \\
\hline Microcel E & 25.56 & \\
\hline Oil Dri & 9.70 & \\
\hline \multicolumn{3}{|l|}{ HD Polyethylene, (-CH2-CH2-) } \\
\hline Vermiculite & & 1.14 \\
\hline Leaded rubber & & 2.40 \\
\hline Teflon & & 0.04 \\
\hline Latex (surgeons gloves) & & 7.69 \\
\hline \multicolumn{3}{|l|}{ Magnesium } \\
\hline \multicolumn{3}{|l|}{ Nickel } \\
\hline \multicolumn{3}{|l|}{ Antimony } \\
\hline \multicolumn{3}{|l|}{ Zinc } \\
\hline & & \\
\hline & & \\
\hline & & \\
\hline & & \\
\hline & & \\
\hline Totals & 100.00 & 100.00 \\
\hline
\end{tabular}

FEEDMIX.XLS 
electrode voltage, current and power, (c) various temperatures in the melter and the offgas system, (d) various pressures in the melter and the offgas system, and (e) various gas and liquid flowrates.

Process samples were collected during or after each test for the slag product (collected during slag tapping), metal product (when metal was tapped), cyclone and baghouse catches, and scrubber solution. Analytical results of these samples will be used to (a) perform mass balances, (b) calculate partitioning and fate of metal and surrogate TRU elements in the feed, (c) determine if the secondary streams are hazardous, and (d) evaluate the physical and chemical properties of the vitrified slag and metal phases.

Additional offgas measurements and sample collection was also performed by Entropy Incorporated and Argonne National Laboratory-East, and Clean Air Engineering. These measurements and sampling runs were conducted at selected locations in the furnace and the APCS. Gaseous measurements included velocity, temperature, and continuous monitoring of gas composition $\left(\mathrm{O}_{2}, \mathrm{CO}, \mathrm{CO}_{2}, \mathrm{NO}, \mathrm{NO}_{2}, \mathrm{SO}_{2}, \mathrm{THC}\right.$, and $\left.\mathrm{HCl}\right)$. These measurements were performed according to EPA methods 1, 2, 3A, 6C, 7E, 10, and 25A. Gas temperatures in the melter were done using a shielded thermocouple mounted in a suction pyrometer probe to minimize the effects of thermal radiation on the gas temperature measurement. Samples were also collected for $\mathrm{HCl}, \mathrm{Cl}_{2}, \mathrm{HF}$, and $\mathrm{F}_{2}$ analysis using a modified EPA Method 26 procedure. Total particulate and metals determinations were done using the draft EPA Method 29, modified to include measurement of total particulate in addition to metals. Dioxin tests were also performed using EPA Method 23 at the baghouse outlet and at the stack.

Argonne National Laboratory and Clean Air Engineering performed Fourier Transform Infrared (FTIR) gaseous analysis at the furnace outlet, the baghouse outlet, and the stack. Species that were monitored included $\mathrm{CO}, \mathrm{CO}_{2}, \mathrm{NO}_{\mathrm{x}}, \mathrm{SO}_{2}$, and various chlorinated and non-chlorinated hydrocarbons. The draft FTIR sampling and analysis procedure that Argonne and Clean Air Engineering has submitted to the US Environmental Protection Agency was used for these measurements.

Sample Analysis

All of the planned sample analyses will be conducted at the USBM laboratory except for the dioxin analyses. Some metals ( $\mathrm{As}, \mathrm{Ba}, \mathrm{Ce}, \mathrm{Cr}, \mathrm{Cs}, \mathrm{Cu}, \mathrm{Ni}, \mathrm{Pb}, \mathrm{Ti}, \mathrm{Zn}$, and $\mathrm{Zr}$ ) will be performed by ion-coupled argon plasma spectroscopy (ICP). Other metals ( $\mathrm{Al}, \mathrm{Ca}, \mathrm{K}, \mathrm{Mg}$, and $\mathrm{Na}$ ) will be analyzed by graphite furnace atomic absorption spectroscopy (GFAAS), depending on the metal species and the necessary detection limits. Sulfur and carbon will be determined using a LECO CS 144 gas analyzer. Total iron and ferrous iron will be determined by USBM IC 9240 analysis, which is a wet chemistry technique that includes oxidation by potassium dichromate followed by dichromate titration. Silicon will also be determined by USBM IC 9240, using gravimetric dehydration. Physical properties and crystalline structures will be determined using optical and scanning electron microscopy. Leachability will be determined using the Toxicity Characteristic Leachability Procedure (TCLP) and the Product Characterization Test-1 (PCT-1) procedure.

\section{RESULTS AND CONCLUSIONS}

The demonstration tests were very successfully conducted by the USBM on surrogate INEL alpha-contaminated wastes on April 11-14, 1995. This was the first vitrification demonstration of surrogate wastes that contained large amounts of combustibles, halocarbons, nitrates, and hydroxides in this type of melter system. These tests show the potential for processing as-received buried and 
mixed wastes in an electric arc melter without prior incineration. The tests also indicate several areas for potential optimization to assure safe and stable furnace system operation and provide an acceptable slag waste form.

The test matrix and some preliminary results are shown in Table 3. The melter system was operated continuously for 66 hours of operation, including 6 hours of cleanout, but not including around 18 hours of preheating and pretesting. Over 20,000 lb of feed mixtures were processed representing the nominal mixture mixed with from $40-90 \%$ soil, the $S$ mixture without added soil and with $40 \%$ soil, and the $C$ mixture with $20 \%$ and $40 \%$ soil. Around $13,000 \mathrm{lb}$ of slag and $1,800 \mathrm{lb}$ of metal were tapped from the furnace. The average power level was around $200 \mathrm{~kW}$, and the average feedrate was around $500 \mathrm{lb} / \mathrm{hr}$. The resulting energy efficiency was around $0.40 \mathrm{kWhr} / \mathrm{lb}$.

The feedrate and feed mixture objectives were met for all feed materials. Operations rapidly progressed from Nom-90 to Nom-60. The furnace was operated reasonably stably for several hours on Nom- 60 while a variety of offgas measurements and slag samples were obtained, according to plan. Various measurements were made and samples were also collected for the other feed mixtures.

The furnace processed all of the different planned feed mixtures. The furnace power was very steady for all conditions except for the S-0 feed mixture, as expected. Arcing was observed at one time during the S-0 test from the electrodes to a quartz glass sample probe that was inserted through the wall of the furnace, between the electrodes. This arcing may have occurred due to the (a) highly conductive gas, which contained quantities of $\mathrm{HCl}, \mathrm{Cl}_{2}$, and soot particles, and (b) presence of an electrically conductive soot layer of around $1 \mathrm{~mm}$ on the otherwise non-conductive quartz probe.

All of the slag produced from the melter appeared to be acceptable with the exception of the slag for the C-20 feed mixture. This slag seemed to contain calcium carbide, based on physical inspection of the tapped slag. The calcium carbide apparently formed under reducing conditions in the furnace. Sample analysis will verify the slag composition and leachability. Furnace design and operation modifications that can be done, if necessary, to more effectively oxidizing the carbon include (a) increasing the primary (furnace combustion) air flowrate, (b) using oxygen or oxygenenriched air for primary air, (c) using solid oxidants, (d) steam injection, or (e) using lancing or tuyeres to obtain better oxygen or steam contact with the carbon in/on the melt.

The offgas system performed as expected. While $\mathrm{CO}$ and unburned hydrocarbons exiting the furnace ranged up to $10 \%$ and $4-5 \%$ respectively (see Table 4 ), the thermal oxidizer readily and efficiently oxidized these species to $\mathrm{CO}_{2}$ and $\mathrm{H}_{2} \mathrm{O} . \mathrm{HCl}$ and $\mathrm{SO}_{2}$ levels at the stack were also typically very low.

There was a tendency for particulate buildup and plugging after several hours of operation in the furnace offgas outlet duct. The inside diameter of the existing water-cooled outlet duct is limited to 8 inches. Particulate buildup seemed to occur at the upper end of the water cooled section, probably from material that first adhered lightly to the refractory above the water-cooled section. Material that sluffed or flowed down from the refractory section to the water-cooled section cooled and more strongly adhered to the top of the water-cooled wall. This deposition was an artifact of the existing furnace roof and outlet duct design and operating conditions.

The feedrate limiting step was the availability of secondary combustion air injected into the thermal oxidizer. The C-20 feed mixture was limited to a feedrate of under $300 \mathrm{lb} / \mathrm{hr}$ when there was insufficient secondary air to completely oxidize furnace offgases and cool the thermal oxidizer by dilution to temperatures under $2,400 \mathrm{~F}$. 
Table 3. Global summary of demonstration tests.

\begin{tabular}{|c|c|c|c|c|c|c|c|c|c|c|}
\hline $\begin{array}{c}\text { Feed } \\
\text { type }\end{array}$ & $\begin{array}{l}\text { Test } \\
\text { day }\end{array}$ & $\begin{array}{l}\text { Operating } \\
\text { run } \\
\text { duration } \\
\text { (hr) }\end{array}$ & $\begin{array}{l}\text { Average } \\
\text { power } \\
(\mathrm{kW})\end{array}$ & $\begin{array}{l}\text { Total } \\
\text { feed } \\
\text { material } \\
\text { (lb) }\end{array}$ & $\begin{array}{c}\text { Average } \\
\text { feedrate } \\
(\mathrm{lb} / \mathrm{hr})\end{array}$ & $\begin{array}{c}\text { Average slag } \\
\text { tapping } \\
\text { rate }(\mathrm{a}) \\
(\mathrm{lb} / \mathrm{hr}) \\
\end{array}$ & $\begin{array}{c}\text { Slag } \\
\text { temp. } \\
\text { at taphole, } \\
\text { average }(\mathrm{C}) \\
\end{array}$ & Range & $\begin{array}{l}\text { Total } \\
\text { slag } \\
\text { tapped } \\
\text { (lb) }\end{array}$ & $\begin{array}{c}\text { Total } \\
\text { metal } \\
\text { product } \\
\text { (lb) }\end{array}$ \\
\hline Nom-90 & 11-Apr & 3.75 & 339 & 1,495 & 399 & 431 & 1,721 & $1,450-1,880$ & 1,616 & - \\
\hline Nom-80 & 12-Apr & 4.08 & 159 & 1,497 & 367 & 383 & 1,597 & $1,400-1,850$ & 1,564 & - \\
\hline Nom-70 & 12-Apr & 11.17 & 175 & 3,998 & 358 & 212 & 1,524 & $1,350-1,700$ & 2,368 & - \\
\hline Nom-60 & 12-Apr & 14.58 & 188 & 3,976 & 273 & 204 & 1,495 & $1,350-1,675$ & 2,970 & 1,004 \\
\hline Nom-50 & 13-Apr & 4.17 & 194 & 1,486 & 987 & - & no tap & no tap & - & - \\
\hline Nom-40 & 13-Apr & 1.25 & 221 & 977 & 782 & 547 & 1,472 & $1,400-1,550$ & 684 & - \\
\hline S-40 & 13-Apr & 6.1 & 196 & 1,594 & 261 & - & no tap & no tap & - & - \\
\hline S-0 & 14-Apr & 10.15 & 147 & 1,098 & 1,117 & - & no tap & no tap & - & - \\
\hline C- 20 & 14-Apr & 1.08 & 191 & 300 & 278 & - & no tap & no tap & - & - \\
\hline $\mathrm{C}-40$ & 14-Apr & 3.83 & 230 & 497 & 130 & 218 & 1,641 & $1,400-1,725$ & 834 & - \\
\hline Cleanout & 14-Apr & 6 & & 3,286 & & & & & 2,804 & 822 \\
\hline Totals (for all days) & & 66.16 & 204 & 20,204 & 495 & 332 & & & 12,840 & 1,826 \\
\hline
\end{tabular}


Table 4. Typical ranges of offgas conditions.

\begin{tabular}{|c|c|c|c|c|c|c|c|c|}
\hline \multirow[b]{2}{*}{ Location } & \multicolumn{7}{|c|}{ Gas composition, dry } & \multirow{2}{*}{$\begin{array}{c}\text { Tempera- } \\
\text { ture, } \\
\text { degrees } \\
\text { F }\end{array}$} \\
\hline & $\begin{array}{l}\mathrm{O}_{2} \\
\%\end{array}$ & $\begin{array}{l}\mathrm{CO}, \\
\mathrm{ppm}\end{array}$ & $\begin{array}{l}\mathrm{CO}_{2} \\
\%\end{array}$ & $\begin{array}{l}\mathrm{NO}_{\mathrm{x}}, \\
\text { ppm }\end{array}$ & $\begin{array}{l}\mathrm{SO}_{2}, \\
\mathrm{ppm}\end{array}$ & $\begin{array}{l}\text { THC, } \\
\mathrm{ppm}\end{array}$ & $\begin{array}{l}\mathrm{HCL}, \\
\text { ppm }\end{array}$ & \\
\hline $\begin{array}{l}\text { Furnace } \\
\text { outlet }\end{array}$ & $0.5-2$ & $\begin{array}{l}5,000- \\
100,000\end{array}$ & $0.1-1$ & $1-100$ & $1-50$ & $\begin{array}{l}500- \\
50,000\end{array}$ & --- & $\begin{array}{c}400- \\
2,000\end{array}$ \\
\hline Stack & $16-19$ & $1-20$ & $1-3$ & $10-40$ & $0.5-1$ & $1-20$ & $0.1-10$ & $90-110$ \\
\hline
\end{tabular}

Additional data analysis and all sample analyses are still underway. An evaluation report is due for completion in the fall of 1995.

\section{ACKNOWLEDGEMENTS}

This work was funded by (a) the DOE Office of Waste Management (EM-30) through the Idaho Waste Processing Facility, Advanced Mixed Waste Treatment Project, (b) the DOE Office of Technology Development (EM-50) through the Buried Waste Integrated Demonstration Arc Melter Vitrification Project, and (c) the USBM.

\section{REFERENCES}

1. Eddy, T.L., B.D. Raivo, N. R. Soelberg, and O. Wiersholm, "Advanced Mixed Waste Treatment Project Melter System Preliminary Design Technical Review Meeting", INEL-950054, February 1995.

2. Soelberg, N. R., A. G. Chambers, G. L. Anderson, L. L. Oden; W. K. O'Connor, and P. C. Turner, "Arc Melter Demonstration Baseline Test Results," EGG-WTD-11138, July 1994.

3. Soelberg, N. R., P.C. Turner, L. L. Oden, and G. L. Anderson, "Test Plan for the BWID Phase 2 Electric Arc Melter Vitrification Tests", INEL-94/0004, October 1994.

4. Roesener, W. S., N. R. Soelberg, and A. L. Ayers, "Identification of a Treatment Process for the Idaho Waste Processing Facility", EG\&G Idaho internal report, September 1992.

5. Bates, S. O, "Definition and Compositions of Standard Wastestreams for Evaluation of BuriedWaste In tegrated Demonstration Treatment Technologies, " EGG-WTD-10660, June 1993.

\section{DISCLAIMER}

This report was prepared as an account of work sponsored by an agency of the United States Government. Neither the United States Government nor any agency thereof, nor any of their employees, makes any warranty, express or implied, or assumes any legal liability or responsibility for the accuracy, completeness, or usefulness of any information, apparatus, product, or process disclosed, or represents that its use would not infringe privately owned rights. Reference herein to any specific commercial product, process, or service by trade name, trademark, manufacturer, or otherwise does not necessarily constitute or imply its endorsement, recommendation, or favoring by the United States Government or any agency thereof. The views and opinions of authors expressed herein do not necessarily state or reflect those of the United States Government or any agency thereof. 